\title{
中国語母語話者を対象とした総合日本語クラスにおける音声指導 一シャドーイングを導入した指導実践からー
}

Teaching Pronunciation by Using Shadowing in Comprehensive Japanese Class for

Chinese Native Speakers

\section{大久保 雅子 \\ 東京大学日本語教育センター}

\section{要旨}

本稿は、総合日本語コースにおける中国語母語話者を対象とした音声指導の実践を 報告し、学習者の発音上の問題点および効果的な指導の方法を検討するものである。

学習者の提出した「フェイスシート」、「アンケート」および「フォローアップ・ インタビュー」の分析から、音韻知識の導入が学習者の発音の意識化を促すことが 明らかになり、音声指導において、音韻知識を導入することの重要性が示された。 また、学習者はプロソディー・シャドーイングの効果を実感しており、プロソディー・ シャドーイングを活用した自律学習へと繋がっていく可能性が示唆された。学習者が 提出した「録音課題」の分析では、アクセントの習得の難しさが浮き彫りとなった。 本分析から、誤用の多い語が明らかになったため、今後の音声指導で、誤用の多い語 に焦点を当てた指導が可能となった。さらに、音声指導の継続および自律学習の必要 性が示された。

キーワード :

プロソディー・シャドーイング、音韻知識、中国人学習者、リズム、アクセント 


\section{中国語母語話者を対象とした総合日本語クラスにおける音声指導 \\ ーシャドーイングを導入した指導実践からー}

\section{大久保 雅子 \\ 東京大学日本語教育センター}

\section{1.はじめに}

\section{1 日本語教育現場における音声指導}

現在、日本語教育現場において、様々な方法で音声指導が行われるようになり、 教育機関によっては、発音に特化した科目も設置されるようになってきた。しかし、 このような科目で行われる音声指導は音声を専門とした教師が行うことが多く、その 指導法は様々であり、学習者が音声指導によってどこまで音韻習得できたかという 研究はまだ十分ではない。一方、近年、日本語の発音教材も複数出版されており、 これらの教材を使用して音声を専門としない教師が音声指導を実践することも可能 となった。しかし、現場の教師からは未だに「どう音声指導したら良いかわからない」 という声が多く聞かれる。これらの声から、日本語の発音教材を自分の教育現場でじ う応用すればよいのかわからないということが推察され、授業における具体的な指導 方法の発信が必要である。さらには、総合日本語クラスのような授業では、「授業の 進度が厳密に決められ、なおかつティームティーチングで行われることが多いため、 授業のスケジュールを守ることが優先され、個々の教師が音声指導を行いたいと 思っても時間が取れない（田川ほか 2015）」という問題点も指摘されている。この ような授業においても音声指導を行うためには、限られた時間で効率的に音声指導を 行うことが求められる。

日本語の音声研究においては、母語（母方言）別、および音声項目別に研究が 行われており、多くの成果が得られているが、それらの研究成果が教育現場に十分に 活かされているとは言い難い。日本国内の教室環境には、様々な母語を持つ学習者が 集まっているため、母語（母方言）別および音声項目別の研究成果を教育現場にどう 活かせるのかという検討はまだなされていない。学習者の音韻習得のためには、音声 教育を体系的に行うことが重要であり、現場の教師は日本語音声の何を教え、学習者 によ゙のような練習が必要なのかを理解し、個々の教育現場に合わせて、取り上げる 音声項目を絞り込むことも検討しなければならない。これは日本国内の教育現場に 限ったことではなく、異なる母方言を持つ学習者が集まっている中国国内の教育現場 においても同様であろう。 
本稿では、限られた時間で行った中国人日本語学習者に対する音声指導実践を報告 し、導入したプロソディー・シャドーイングの効果、学習者の発音上の問題点および 効果的な指導の方法を検討する。

\section{2 プロソディー・シャドーイング}

近年、日本語授業にシャドーイングを導入する取り組みが数多く行われており、 シャドーイングに関する研究成果も複数報告されているが、中国語母語話者を対象と してプロソディー・シャドーイングを導入した取り組みの報告は多くない。シャドー イングには意味理解に焦点を当てたコンテンツ・シャドーイングと、音声面に焦点を 当てたプロソディー・シャドーイングがあり、プロソディー・シャドーイングは 音声習得、特に韻律部分に有効であることが指摘されている（阿・林 2010）。した がって、学習者の音韻習得を促すためには、コンテンツ・シャドーインツではなく プロソディー・シャドーイングの練習方法を身につけさせることが大切である。

戸田・大久保（2011）は、学習者にシャドーイング練習による自律学習を促した 場合、どのような気づきが生まれるかを調査したが、気づきの内容を分類した結果、 「アクセント」、「イントネーション」、「単音・特殊拍」の順で多かったと述べている。 さらに、授業で導入した日本語の音韻知識がシャドーイング実践における気づきを 促すということを明らかにしている。また、大久保ほか（2013）では、異なる日本語 レベルの教室活動において 5 週間にわたるシャドーイング実践を行い、個々の語の アクセントを示さずともアクセント習得が促されることが示唆されている。郭 (2014) では、中国語を母語とする初・中級日本語学習者を対象にプロソディー・シャドー イングを遂行し、長音と促音の口頭産出が改善されたことが報告されている。これら の先行研究から、音声指導で音韻知識を導入し、プロソディー・シャドーイングを 活用することによって、アクセントや特殊拍の改善が期待される。

\section{2. 音声指導実践}

今回、音声指導を実施した授業は、日本国内にある大学の総合日本語クラスである。 総合日本語クラスとは、「読解」、「聴解」、「文章表現」、「口頭表現」の4 技能 を扱うコースである。本コースは半年ないし 1 年間の中国からの留学プログラムで、 日本語レベルは中級に相当する。本稿では、2019 年度秋学期を対象として分析を 行った。なお、当学期の履修者は 12 名であった。 


\section{1 音声指導の内容}

音声指導を行ったのはスケジュール全 140 コマのうち 7 コマ'である。各音声指導 の内容を表 1 に示す。全 140 コマのうち 7 コマしか音声指導ができなかったのは、 ティームティーチングで 4 技能を扱うシラバスとなっているため、全体で音声指導に 割けるコマは 7 コのみという状況があったためで、この 7 コマの中で効率的に指導 を行う必要があった。

本音声指導で目指したのは、「音韻知識の獲得」、「発音の意識化の促進」、「自律 学習」である。授業では、「音韻知識の獲得」のために、教師が音韻知識を導入し、 復習クイズによって音韻知識の確認を行った。また、録音課題の提出および教師の フィードバックにより、学習者に自らの問題点を把握させることで「発音の意識化の 促進」を図った。さらに、授業で学習者がプロソディー・シャドーイングを正しく 行っているかどうかを確認し、プロソディー・シャドーイングを活用した「自律学習」 を促した。

\section{表 1 各音声指導の内容}

\begin{tabular}{|c|c|c|c|}
\hline 回（日付） & 内容 & 回（日付） & 内容 \\
\hline 第 1 回（10月 4 日） & シャドーイング & 第 2 回（10 月 25 日） & リズム \\
\hline 第 3 回（11月 8 日） & 複合語アクセント & 第 4 回（11月 22 日） & 動詞アクセント \\
\hline 第 5 回（11月 29 日） & オノマトペ & 第 6 回（12月 13 日） & 連濁 \\
\hline 第 7 回（12月 20 日） & イントネーション & & \\
\hline
\end{tabular}

第 1 回では、シャドーイングを紹介し、プロソディー・シャドーイングを導入した。 練習方法の説明では、コンテンツ・シャドーイングとの違いを認識させ、「意味では なく、音に意識を向ける」、「聞き取れたところだけシャドーイングすればよい」と いう 2 点を強調した。授業で行った練習方法は以下のとおりである。

1）スクリプトなしのリスニングで大意を把握

2） スクリプトなしでプロソディー・シャドーイング

3 ） スクリプトを見ながらパラレルリーディング2

4） スクリプトなしでプロソディー・シャドーイング

\footnotetext{
1 本コースは週 10 コマ、14 週間のスケジュールが組まれている (全 140 コマ)。本コースの留学 生は全ての授業を受講することとなっている。

2 パラレルリーディングとは、音声と同時に音読するものであり、門田・玉井（2004）の練習 方法を援用した。
} 
本音声指導では、2 回ともスクリプトなしでプロソディー・シャドーイング練習を 行った。教室外で自律学習としてプロソディー・シャドーイングを行う場合、テレビ のニュースやドラマ等の身の回りの音声で行うことが想定され、スクリプトがない 状況が普通である。そのため、スクリプトがない状態のシャドーイングに慣れさせ、 シャドーイング練習を毎日、継続していくことを促した。

第 2 回では、日本語の拍を確認し、学習者にとって習得が難しいとされている特殊 拍を扱うために、リズムを取り上げた。まずは特殊拍および拗音を含む単語の拍数を 確認し、特殊拍および拗音が 1 拍分の長さがあることを意識させた。次に、2 拍フット を導入し、「よかった」は「○○（タ・タン・タ）」のように、リズムの作り方 を練習した。

第 3 ～ 5 回は、中国語の声調の影響でピッチの上げ下げが多くなってしまいがちな 「アクセント」を取り上げることにした。まず、日本語のアクセントルールを紹介し、

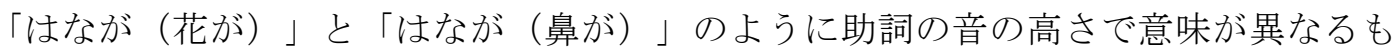
のがあるため、助詞の音の高さまで意識するよう注意を促した ${ }^{3}$ 。第 3 回で「複合語 のアクセント」を扱ったのは、複合語のアクセントはルールを覚えれば、一つ一つの 語のアクセントを知らずとも正しいアクセントがわかるからである。まずは、「けい

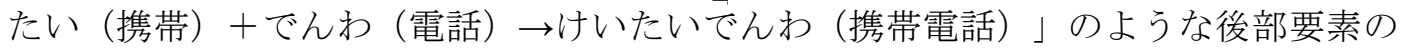
最初の拍にアクセント核を付与するルールを導入し、大学名（○○だいがく）や料理 名（○○りょうり）等で練習を行った。次に、後部要素が短いことば（2 拍以下）の とき、前部要素の最後の拍にアクセント核を付与するルールを導入し、駅名や県名、 「国名十人」で練習を行った。なお、「国名十人」のところでは、最も使用頻度が高い 一つである「にほんじん（日本人）」は例外であることも紹介した。なお、「後部要 素が-2 型ではない中高型の場合、元のアクセントが残る」というルール、「後部要素 が長いことば（5 拍以上）のとき、元のアクセントが残る」というルールは割愛した。 これは、この二つのルールを導入する十分な時間がなかったこと、また、二つとも 学習者が後部要素のアクセントを知らなければ複合語のルールもわからないためで ある。そこで、元の語のアクセントを知らなくても正しいアクセントがわかる後部 要素の最初の拍にアクセント核を付与するもの、前部要素の最後の拍にアクセント核 を付与するものに焦点を当てて練習を行った。

3 大久保 (2019) では、中国人学習者の発音上の誤用の中で、助詞のアクセントの誤用数が名詞 のアクセントより上回り、学習者も助詞のアクセントの難しさを自己認識していたことが明ら かになっている。 
第 4 回では「動詞のアクセント」を扱った。動詞のアクセントには 2 種類あり、 平板式動詞と起伏型動詞に分けられる。どちらの動詞かさえ覚えれば正しい アクセントがわかるため、日常生活で使用頻度の高い動詞を提示して練習を行った。 さらに、動詞の活用形のアクセントの確認を行った。その際、動詞の「ナイ形」に 注意を促した。劉（2012）による北京・上海方言話者の動詞・複合動詞アクセントの 研究で、アクセント核が軽音節より重音節に置かれる傾向があり、その影響で動詞の 「ナイ形」では「〜ない」のアクセントパターンの誤用が多いことが明らかになって いる。そのため、学習者に平板式動詞の「ナイ形」はアクセント核を置かず、起伏式 動詞の「ナイ形」は「ない」の前にアクセント核を置いて発音するよう意識を向け させた。

第 5 回の「オノマトペのアクセント」もルールさえ知っていれば正しいアクセント がわかるものである。オノマトペには 2 種類のアクセントがあり、「ぺらぺら話す」 は頭高型、「ペらぺらです」のように「です」がつくと平板型になることを説明して、 日常会話で使用頻度が高いオノマトペを導入しながらアクセント練習を行った。 さらに、「ころころ」／「ごろごろ」、「きらきら」／「ぎらぎら」のように、濁点の 有無で意味が異なることも紹介した。

また、第 6 回では、中国語の有気・無気の影響によって混同が引き起こされる 「無声・有声破裂音（以下、清濁）」を意識させるために「連濁」を取り上げた。連濁 になる語と連濁にならない語を学習者に挙げさせ、連濁にならないものにどのような 共通点があるかを考えさせ、連濁の特徵の理解を促し、清濁の発音の練習を行った。

最後に、コミュニケーションにおいて重要な役割を果たす「イントネーション」を 第 7 回で取り上げ、同じ表現であっても「驚き・喜び」、「落胆」、「ためらい」の 気持ちによって、どのようにイントネーションが変化しているかを考えさせた。ここ では、自分がイントネーションを使い分けることだけでなく、話し手の気持ちを理解 することの重要性を強調した。

本音声指導では、以上の音韻知識を導入し、発音の意識化を促した。なお、音韻 知識の定着を図るために、次回の授業で筆記形式の復習クイズを実施した。例えば、 単語の拍数を答える問題やリズムを書かせる問題、複合語にアクセントを書き入れる 問題、動詞のアクセントの種類を答える問題等を出題した。 


\section{2 録音課題}

7 コマの音声指導のうち、宿題として 5 回の録音課題を課した。課題文は 『シャドーイングで日本語発音レッスン』（2012）の本文から選定した。学習者は 課題文を $\mathrm{CD}$ の音声で練習し、読み上げたものを録音し、音声ファイルの提出を 行った。提出された音声ファイルは筆者が発音をチェックしてフィードバックシート を作成し、次回の授業で学習者にシートを渡してフィードバックを行った。大久保 ほか（2014）および大久保（2019）では、問題点に対する具体的な解説は行わず、 簡単な指摘 ${ }^{4}$ 行うことによって、学習者がモデル音声と自分の提出した録音音声を 聞き比べ、問題点を自分で発見し、自己モニターを働かせて自己調整できたことが 明らかになっている。また、簡単な指摘であれば、音声を専門としない教師でも フィードバックが可能である。そこで本フィードバックでもその方法を援用すること とした。

\section{3. 調查}

本稿では教室活動における効果的な音声指導の方法を提案するために、以下の リサーチ・クエスチョンを設定した。

1）音声指導によって、学習者の発音に対する意識が変化したか。

2）プロソディー・シャドーイングは学習者にとって効果的な練習方法で あったか。

3 ）音声指導後、学習者によ゙のような発音上の問題点が残るか。

以上の点を検討するために、学習者がコース前に提出したフェイスシート、コース 後に提出したアンケート、フォローアップ・インタビュー、宿題として課せられた 録音課題の最終課題（第 5 回）の分析を行った。

\section{1 中国における音声指導の有無}

フェイスシートおよびフォローアップ・インタビューの文字化資料から、学習者の 来日前における音声指導の有無を分析した。その結果を表 2 に示す。

4 フィードバックの詳細は大久保（2019）を参照されたい。 
表 2 音声指導の有無

\begin{tabular}{|c|c|c|c|c|}
\hline 学習者 & 母方言 & 大学の所在地 & 来日前の日本語学習 & 音声指導の有無 \\
\hline A & 四川語 & 上海市 & 大学 & ○(大学の日本語授業で) \\
\hline $\mathrm{B}$ & 無 & 上海市 & 大学 & ○(大学の日本語授業で) \\
\hline $\mathrm{C}$ & 泰州語 & 南京市 & 大学 & ○(大学の日本語授業で) \\
\hline $\mathrm{D}$ & 長沙語 & 長沙市 & その他 & $\times$ \\
\hline $\mathrm{E}$ & 無 & 長春市 & 大学 & ○(大学の日本語授業で) \\
\hline $\mathrm{F}$ & 上海語 & 上海市 & 大学 & ○(大学の日本語授業で) \\
\hline G & 上海語 & 上海市 & 大学 & ○(大学の日本語授業で) \\
\hline $\mathrm{H}$ & 無 & 哈爾浜市 & 大学 & ○(大学の日本語授業で) \\
\hline I & 上海語 & 上海市 & 大学 & ○(大学の日本語授業で) \\
\hline $\mathrm{J}$ & 上海語 & 上海市 & その他 & $x$ \\
\hline $\mathrm{K}$ & 关中語 & 長春市 & 大学 & ○(大学の日本語授業で) \\
\hline $\mathrm{L}$ & 四川語 & 上海市 & 大学 & ○(大学の日本語授業で) \\
\hline
\end{tabular}

表 2 からわかるとおり、12人中 10 人の学習者が「音声指導有り」と答えており、 音声指導を受けた場所は中国の大学の日本語授業であった。

次に、「音声指導有り」と回答した学習者に、どの授業でどのような指導があった のかをフォローアップ・インタビューで聞いたところ、全員が「聴解」や「会話」の 授業で音声指導を受けたと回答した。また、その内容は、「テキストを読む」、「モデル 音声をリピートする」、「テキストをシャドーイングする」、「学習者の発音上の問題 点を教師が指摘し、リピートする」というものであり、音韻知識を学んでいないこと がわかった。この結果から、学習者は音韻知識がない状態で発音練習を行っているこ とが示された。

\section{2 指導前後の学習者の発音に関する自己認識}

フェイスシートの質問項目「自分の発音に問題点があると思いますか。その場合は その問題点を詳しく書いてください」の記述内容、およびアンケートの質問項目

「現在の自分の発音の問題点は何ですか」の記述内容を表 3 に示す。 
表 3 指導前と指導後の発音上の問題点

\begin{tabular}{|c|l|l|}
\hline 学習者 & \multicolumn{1}{|c|}{ 指導前の問題点 } & \multicolumn{1}{|c|}{ 指導後の問題点 } \\
\hline A & 音の高低 & 清濁の聞き分け \\
\hline B & 読むときは大丈夫だが、話すとき間違える & 時々、中国語っぽい発音が出てくる \\
\hline C & 流暢ではない & 動詞のアクセント \\
\hline D & アクセント & 長い文のアクセント \\
\hline E & アクセント & 動詞のアクセント \\
\hline F & 長い文 & 長い文のアクセント \\
\hline G & 特殊拍、アクセント & 読み間違い \\
\hline H & 自分の発音は一般的 & 発音が固い \\
\hline I & 促音、長音 & 長音 \\
\hline J & 音の高低 & 長い文のアクセント \\
\hline K & 自然さが足りなくて流暢ではない & 緊張するとアクセントが変になってしまう \\
\hline L & 中国語の影響で発音がきれいではない & 時々、音の高低がわからない \\
\hline
\end{tabular}

表 3 から、指導前の発音上の問題点で、アクセント（音の高低）、特殊拍、促音、 長音のように、具体的に問題点が挙げられていることがわかる。音声に特化した 選択科目の学習者の場合は、自分の発音に対する意識が高いことが推測されるが、 今回のような総合日本語コースの学習者であっても発音に対する意識が高いことが わかった。これは、今回の学習者の多くが中国の大学で音声指導を受けており、

リピート練習や教師の指摘等によって自己の問題点を認識できていたためであると 考えられる。指導前と指導後の発音上の問題点を比較すると、多くの学習者の問題点 が具体化されたり、絞り込まれたりしていることがわかる。また、指導前と指導後で 問題点が変化した学習者もおり、A は新たな問題点を発見したことがわかった。「時々、 中国語つぽい発音が出てくる(B)」、「発音が固い $(\mathrm{H}) 」$ のような場合、問題点が具体 化されていないため5、さらなる音声指導が必要であろう。

次に、アンケートに記述されていた音声指導の授業の感想および発音の変化の有無 を表 4 に示す。

5 フォローアップ・インタビューで、学習者は漠然と問題点を認識しており、なぜそのような発 音になるのかがわかっていなかったことが示されている。 
表 4 音声指導の感想および自己認識している発音・意識の変化の有無

\begin{tabular}{|c|c|c|}
\hline 学習者 & 音声指導の感想 & 発音·意識の変化の有無 \\
\hline $\mathrm{A}$ & 前に知らなかった知識が得られた & $\begin{array}{l}\text { 有（自分の発音に気を配ることができる } \\
\text { ようになった） }\end{array}$ \\
\hline $\mathrm{B}$ & $\begin{array}{l}\text { アクセントやイントネーションの知識は } \\
\text { 初めてだったので、たくさん勉強になった }\end{array}$ & $\begin{array}{l}\text { 有（発音の正しさをもっと大切にする } \\
\text { ようになった） }\end{array}$ \\
\hline $\mathrm{C}$ & 動詞のアクセント知識が役に立った & $\begin{array}{l}\text { 有（動詞や助詞のアクセントに気がつく } \\
\text { ようになった） }\end{array}$ \\
\hline $\mathrm{D}$ & $\begin{array}{l}\text { 役に立った知識や練習がたくさんあるが、 } \\
\text { もっと練習を増やしてほしかった }\end{array}$ & $\begin{array}{l}\text { 有（アクセントが少し日本人っぽく } \\
\text { なった） }\end{array}$ \\
\hline $\mathrm{E}$ & アクセントの知識が役に立った & 有（なめらかになった） \\
\hline $\mathrm{F}$ & $\begin{array}{l}\text { 動詞のアクセント知識が役に立った } \\
\text { 聞く能力が向上した }\end{array}$ & 有 (アクセントを意識するようになった) \\
\hline $\mathrm{G}$ & 録音課題のフィードバックが役に立った & 有（以前より自然になった） \\
\hline $\mathrm{H}$ & 動詞のアクセントの知識が役に立った & $\begin{array}{l}\text { 有（日本人と話す時、発音を注意する } \\
\text { ようになった） }\end{array}$ \\
\hline I & 自分のアクセントに注意し始めた & $\begin{array}{l}\text { 有（長音、促音、助詞のアクセントが } \\
\text { 自然になった） }\end{array}$ \\
\hline $\mathrm{J}$ & 多くの誤った発音を変えることができた & 有（少し進歩している） \\
\hline $\mathrm{K}$ & $\begin{array}{l}\text { 発音の知識が得られた } \\
\text { 発音練習方法がわかった }\end{array}$ & $\begin{array}{l}\text { 有（昔は発音の問題をあまり重視してい } \\
\text { なかったが、今は重視するようになった） }\end{array}$ \\
\hline $\mathrm{L}$ & $\begin{array}{l}\text { 日常会話でアクセントに注意するように } \\
\text { なった }\end{array}$ & $\begin{array}{l}\text { 有（動詞のアクセントに注意するように } \\
\text { なった） }\end{array}$ \\
\hline
\end{tabular}

音声指導の授業の感想から、音韻知識が役に立ったと感じている学生、発音に意識 が向いたと感じている学生が多いことがわかる。中国の大学で音声指導を受けた学生 たちが、本音声指導での音韻知識が役に立ったと感じていることから、音声指導で リピートおよび発音訂正をするだけでなく、音韻知識の導入が学習者の音韻習得に 大きな役割を果たす可能性が示された。また、全員が自分の発音や意識が変化したと 感じており、本音声指導が学習者の発音の意識化を促したと考えられる。

\section{3 シャドーイング練習に対する学習者の捉え方}

本音声指導では、正しいシャドーイングの練習方法を身に付け、発音に意識を向け ていくことを目指した。アンケートの「シャドーイング練習はどうだったか」という 質問項目および「今後も発音練習を続けるか」の質問項目の回答を表 5 に示す。 


\begin{tabular}{|c|c|c|}
\hline 学習者 & シャドーイング練習はどうだったか & 今後も発音練習を続けるか（方法） \\
\hline A & 正確な日本語の発音に役に立った & はい（シャドーイング） \\
\hline $\mathrm{B}$ & $\begin{array}{l}\text { だんだんシャドーイングに慣れて、日常生活 } \\
\text { でもシャドーイングするようになった }\end{array}$ & はい（シャドーイング） \\
\hline $\mathrm{C}$ & 難しい（意味を考えてしまう） & はい（テレビ） \\
\hline $\mathrm{D}$ & よく練習する & はい（ニュース） \\
\hline $\mathrm{E}$ & アクセントとリズムに効果がある & はい（シャドーイング） \\
\hline $\mathrm{F}$ & ドラマで練習した & はい（シャドーイング） \\
\hline $\mathrm{G}$ & ゆっくりならできる & はい（シャドーイング） \\
\hline $\mathrm{H}$ & 効果がある & はい（シャドーイング） \\
\hline I & 音に注意する & はい（シャドーイング） \\
\hline $\mathrm{J}$ & 役に立った & はい（日本のドラマやニュースを聞く） \\
\hline $\mathrm{K}$ & 練習すればするほど効果がある & はい（シャドーイング） \\
\hline $\mathrm{L}$ & 時々練習する & はい（日本人の発音をシかドーイイグ） \\
\hline
\end{tabular}

表 5 の「シャドーイング練習はどうだったか」という質問項目の回答から、シャドー イング練習を肯定的に捉え、シャドーイングの効果を実感している学習者が多いこと がわかった。一方、C はプロソディー・シャドーイングが難しいと述べている。C 意味を考えるコンテンツ・シャドーイングになってしまっていて、プロソディー・ シャドーイングができていないと自覚できていることがわかる。日本語中級レベル 以上になると、無意識のうちに意味を考えてしまう傾向があるため、学習者によって は意味ではなく音に集中することは難しい場合がある。プロソディー・シャドー イングの効果を最大限に引き出すためには、音に集中することが重要であるため、 今後の自律学習でプロソディー・シャドーイングを継続し、音に集中することに慣れ ていく必要がある。

このクラスでは、Eと H が中国の大学でも発音練習としてシャドーイング練習を 行っていたとフォローアップ・インタビューで回答しているが、二人とも発音を 向上させるプロソディー・シャドーイングではなく、意味理解に焦点を当てたコン テンツ・シャドーイングを行っていたことがわかった。本音声指導でプロソディー・ シャドーイングができるようになったことで、今後の発音の向上が見込まれる。 
「今後も発音練習を続けるか」の質問項目では、全員が「はい」と答えており、 12 人中 9 人が方法としてシャドーイングを挙げている。本音声指導でプロソディー・ シャドーイングに慣れたことにより、今後の自律学習に繋がっていくことが期待 される。

\section{4 第 5 回録音課題の誤用分析}

本音声指導後に学習者にどのような誤用が残るのかを明らかにするために、第 5 回 録音課題の誤用を分析した（表 6）。表 6 の「アクセント」をみると、動詞の誤用が 多いことが特徵的である。

表 6 第 5 回録音課題の誤用

\begin{tabular}{|c|c|c|c|c|c|}
\hline アクセント & 誤用数 & リズム & 誤用数 & その他 & 誤用数 \\
\hline 名詞 & 36 & 長音の短音化 & 4 & 読み間違い & 3 \\
\hline 助詞 & 12 & 促音の脱落 & 3 & 清濁 & 2 \\
\hline 助数詞 & 9 & 長音の挿入 & 3 & & \\
\hline 動詞 & 42 & 撥音の挿入 & 2 & & \\
\hline その他 & 3 & 特殊拍の交替 & 2 & & \\
\hline 合計 & 102 & 合計 & 14 & 合計 & 5 \\
\hline
\end{tabular}

第 5 回課題文には動詞の「辞書形」だけでなく、「テ形」、「タ形」、「ナイ形」、 「〜ている」、「〜てみる」、「〜ば」、「受身形」が含まれている。表 3 の指導後の発音 上の問題点で「長い文のアクセント」、「動詞のアクセント」を挙げている学習者が 複数いたことからも、文中に現れた動詞のアクセントが難しかったことが窥える。 この結果から、学習者が動詞のアクセントルールを既習している状態であっても、 さらなる練習の継続が必要であることが示唆された。辞書形のアクセントが分類でき たとしても、文中にある場合はアクセントが崩れてしまうことも考えられるため、 音声指導で動詞のアクセントを一つずつ扱うだけでは不十分であり、文中で動詞の アクセントを正しく発音できるよう練習することが必要となるだろう。

次に多かったのは名詞のアクセントだが、動詞と同様に文中に幾つもの名詞が 連続して現れた場合、モデル音声の音の高低を掴みにくかった可能性がある。名詞の アクセントがわからなかった場合、オンラインアクセント辞書や電子辞書で調べる ことを促していたが、このような習慣を身につけさせ、知っている名詞のアクセント の数を少しずつ増やしていくことが、今後の発音向上に繋がっていくだろう。 
また、リズムの問題も全体の $11.5 \%$ を占めている。「長音の短音化」や「促音の脱 落」だけでなく、「促音の挿入」や「撥音の挿入」もみられていることから、学習者 は特殊拍のみならず、文全体のリズムがじうなっているか意識を高めていき、自分の 発音に対して「自己モニター」を働かせて「自己修正」していく必要がある。

表 6 で誤用の多かった音声項目を示したが、具体的にアクセントの誤用で最も 多かった語を表 7 に示す。表 7 は 12 人中 8 人以上に誤用がみられた語である。

表 7 誤用が多かった語

\begin{tabular}{|c|c|c|c|c|c|}
\hline 誤用 & 人数 & 誤用 & 人数 & 誤用 & 人数 \\
\hline かんじられる (感じられる) & $9 / 12$ & ならない & $9 / 12$ & とうだいじの（東大寺の） & $8 / 12$ \\
\hline
\end{tabular}

誤用が多かった語の誤用パターンを分析すると、全て同じパターンで誤用している ことがわかった。誤用が一番多かった語の一つは、動詞「感じる」の受身形であった。 第 4 回の音声指導では動詞を提示し、平板式と起伏式に分ける練習を行っている。 また、動詞の「テ形」、「タ形」、「ナイ形」の活用形が動詞のアクセントの種類で 異なっていることに注意を向けさせ、モデル音声をしっかり聞いて確認するよう促し ていた。しかし、今回、平板式動詞である「感じる」の受身形のアクセントの誤用が 多かったことから、モデル音声の音の高低をしっかり確認せずに、起伏型動詞の受身 形の「れる」の形で発音してしまった可能性、または、「感じられる」が下がらない ことがわかっていながら、最後まで高さを保ち続けることが難しかった可能性がある。 誤用の原因については別調査が必要となるが、音声指導の観点からは、動詞の活用形 の練習が必要であることは間違いない。劉（2012）で中国語母語話者において平板式 動詞より起伏型動詞の正用率が高いことが明らかになっていることから、誤用の多い 平板式動詞の練習を増やしていくことも有効である可能性がある。

同じく一番誤用が多かった「ならない」は「なる」の否定形である。動詞の「ナイ 形」は音声指導中、重点的に練習した項目である。しかし、本分析結果から、まだ 十分に習得できていないことが浮き彫りとなり、今後のさらなる練習が必要であるこ とが示された。また、「東大寺の（とうだいじの）」のアクセントの誤用も、「なら ない」と同様に重音節にアクセント核が置かれていることから、重音節にアクセント 核を置いてしまう問題点を改善させることの難しさが示された。今後、動詞の「ナイ 形」や、重音節を含む名詞等で練習していくことが求められる。さらに、音声指導で 䛊用が多いアクセントを正しく発音できているかを学習者に自己認識させ、プロソ ディー・シャドーイングを活用した自律学習を促していくことが必要であろう。 


\section{4.まとめ}

本稿では、限られた時間の中で行った中国人日本語学習者に対する音声教育実践を 報告し、「本音声指導によって学習者の発音に対する意識が変化したか」、「プロソ ディー・シャドーイングは学習者にとって効果的な練習方法であったか」、「学習者 にどのような誤用がみられるか」という観点から分析を行った。

学習者のフェイスシート、アンケートの分析から、音声指導で導入したアクセント の知識等の音韻知識が学習者の発音の意識化を促すことが示された。これにより、 ただリピートさせて問題点を指摘するだけの音声指導ではなく、音韻知識の導入も 併せて行うことが重要であることが示唆された。総合日本語クラスのように授業時間 が限られている場合であっても、それぞれの教育現場に合わせた指導計画で、音声 項目を絞り込むことによって、音韻知識の導入は可能である。

また、指導後の発音上の問題点としてアクセントを挙げた学習者が多かったこと から、今後、音声指導以外の授業においても、教師が新しい語を導入する際、アク セントを明示的に示して辞書形と併せて活用形でのアクセント練習を行い、学習者が 正しいアクセントで発音できているかどうか確認する等の指導を行う必要がある。

本音声指導で実施したプロソディー・シャドーイング練習について、学習者は肯定 的に捉えており、自律学習へと繋がる可能性が示された。プロソディー・シャドー イングによって発音の向上を促すためには、「音に集中する」ことが重要である。 意味を考えてシャドーイングする学習者もいるため、最初の段階で学習者にシャドー イングの知識および正しい方法を教えることが大切である。また、プロソディー・ シャドーイングができているかどうかを授業で毎回確認し、自律学習を促していく ことが有効であると考えられる。

学習者の録音課題の誤用分析では、アクセントの誤用を減らしていくことが今後の 重大課題となることが示された。特に、動詞のアクセント知識が得られた状態で あっても誤用が多かったことから、活用形も含め、文の中に入れて練習を行うことが 必要である。特に動詞の「ナイ形」を取り上げて集中的に練習することも有效で あろう。さらに、重音節が含まれる語を取り上げて練習することもアクセント習得を 促すと考えられる。 


\section{中国語母語話者を対象とした総合日本語クラスにおける音声指導}

ーシャドーイングを導入した指導実践からー

本稿では、7コマという少ない時間での音声指導を振り返り、効果検証を行い、「音 声指導では、音韻知識の導入が重要であること」、また「限られた時間でも、項目を 絞り込めば音韻導入は可能なこと」、「プロソディー・シャドーイングを活用して自律 学習を促すことが必要であること」、そして「学習者の誤用の多い語に焦点を当て、 集中した練習が重要であること」という知見が得られた。しかし、学習者は音声指導 後に、教師の指摘がなくとも学習者自身が自分の発音を「自己モニター」し、「自己 修正」できるようになるために自律学習を継続しなければならない。音声指導を 受けた学習者がコースを終了し、次のコースに進んだ後にも自律学習を継続している かどうかを調査し、自律学習の継続に必要な要素を明らかにすることを今後の課題 としたい。 


\section{参考文献}

阿栄娜・林良子（2010）「シャドーイング練習による日本語発音の変化一モンゴル語・中国語母語 話者を対象に一」『電子情報通信学会技術研究報告』SP, 音声, 109（451）。19-24.

大久保雅子 (2019)「総合日本語クラスにおける音声指導一中国人学習者を対象として一」『Lingua』 $29,145-152$.

大久保雅子・張婉明・趙靚（2014）「オンデマンド授業における発音学習支援一メンターによる

「発音チェック」機能を中心に一」『早稲田日本語教育学』16, 39-60.

大久保雅子・神山由紀子・小西玲子・福井貴代美（2013）「アクセント習得を促すシャドーイング 実践一効果的な実践方法を目指して一」『早稲田日本語教育実践研究』1,37-47.

郭昱昕（2014）「中国語を母語とする日本語学習者の日本語文プロソディ・シャドーイングが特殊

音素の産出改善に及ぼす効果一音韻的短期記憶容量とシャドーイング試行数の観点からー」

『広島大学大学院教育学研究科紀要』第二部, 文化教育開発関連領域(63), 225-233.

門田修平・玉井健（2004）『決定版＼cjkstart英語シャドーイング』コスモピア

田川恭識・渡部みなほ・野口芙美・小西玲子・神山由紀子（2015）「総合日本語クラスで日常的 に音声指導を行うための教材開発に向けて一初級日本語クラスにおける実践とその問題点」

『早稲田大学日本語教育実践研究』3,9-24.

戸田貴子・大久保雅子（2011）「日本語学習者の自律学習を促すシャドーイングの実践と気づきー 発音の滑らかさの向上を目指した練習方法に関寸る一考察—」『ヨーロッパ日本語教育』15, 54-60. 戸田貴子・大久保雅子・神山由紀子・小西玲子・福井貴代美（2012）『シャドーイングで日本語 発音レッスン』スリーエーネットワーク

劉佳琦（2012）『東京語の動詞・複合動詞アクセントの習得一北京・上海方言話者を対象として一』 早稲田大学出版 